- national boundaries. Cardiovascular problems are often associated with other disorders - for example, kidney and lung diseases so an approach that cuts across disciplines is important, says cardiac pharmacologist Sian Harding of Imperial College London. "The disease itself doesn't have boundaries," she adds. Samani says that applications could also include researchers outside medicine and biology: for example, artificial-intelligence researchers could help to develop tools that predict the risk of cardiovascular disorders.

\section{GLOBAL COLLABORATION}

It is also encouraging that the foundation is emphasizing international collaboration and the global burden of cardiovascular diseases, says Amitava Banerjee, a cardiologist and data scientist at University College London. "If we really are talking about global need, then we need to get global data - we can't be doing studies only in London and Oxford," he says.

However, Banerjee is concerned that, for all the talk of innovation and transformative research, a grant of this size is likely to go to a team led by well-established, senior scientists who might not be the best source of exciting ideas. He says that medicine needs to move away from this form of "eminence-based" research, and instead take cues from other industries, in which novel and radical ideas often come from people at a much earlier stage of their career. The BHF says that all applications will need to include diverse teams and no matter who the applicants are, they must be prepared to take a "high-risk, high-reward" approach.

The grant carries with it a substantial amount of money - but it is not without precedent, even in the "If we really
are talking
about global
need, then we
need to get
global data." field of cardiovascular research. In 2015, Google Life Sciences (now Verily) and the American Heart Association announced a \$50-million award for research into preventing coronary heart disease. Pharmaceutical company AstraZeneca later climbed on board as well, adding an extra $\$ 25$ million to the pot.

The winner of that grant was Calum MacRae, a cardiologist at Brigham and Women's Hospital in Boston, Massachusetts, who is looking for early markers of coronary heart disease. Compared with smaller pots of funding, large grants can force researchers to think about problems in completely different ways, MacRae says. The grant has enabled his team to work at a faster pace and more collaboratively than might have been possible with more traditional forms of support, he says. "Diversity in funding is as important as diversity in ideas."

Another UK-based charity, Cancer Research UK (CRUK), also awards "Grand Challenge" grants of up to $£ 20$ million to address specific problems. Last year, four teams received funding for projects such as creating virtual-reality maps of tumours and finding ways of preventing unnecessary breast-cancer treatment. Ten teams have been shortlisted for a second round of funding.

The BHF consulted MacRae and CRUK when planning their new award, says Samani. But they decided not to restrict the scope, and instead give researchers leeway to pitch any project related to heart and circulatory disease. "We really trust the research community to come up with the best ideas," he says. "I'm not aware of any other major grant of this scale which is that open." -

\title{
Trump science-adviser pick hedges on climate change
}

\section{Meteorologist Kelvin Droegemeier offered few clues to his views on the topic to US lawmakers.}

\section{BY SARA REARDON}

$\mathrm{K}$ elvin Droegemeier — President Donald Trump's nominee for science adviser - revealed little about his stance on climate change during his nomination hearing before a US Senate committee on 23 August. Some experts attribute his elusiveness to deftly manoeuvering a politically sensitive topic, rather than doubts about the science.

The researcher, a meteorologist whom Trump nominated to lead the White House Office of Science and Technology Policy (OSTP) on 31 July, told committee members that science should be conducted without political interference or influence. "I am absolutely firm on the point," Droegemeier said.

But he equivocated on whether views that are in the minority, such as doubts about the human role in climate change, should be included in policymaking decisions. "Science never provides immutable evidence about anything," he said. "I think science is the loser

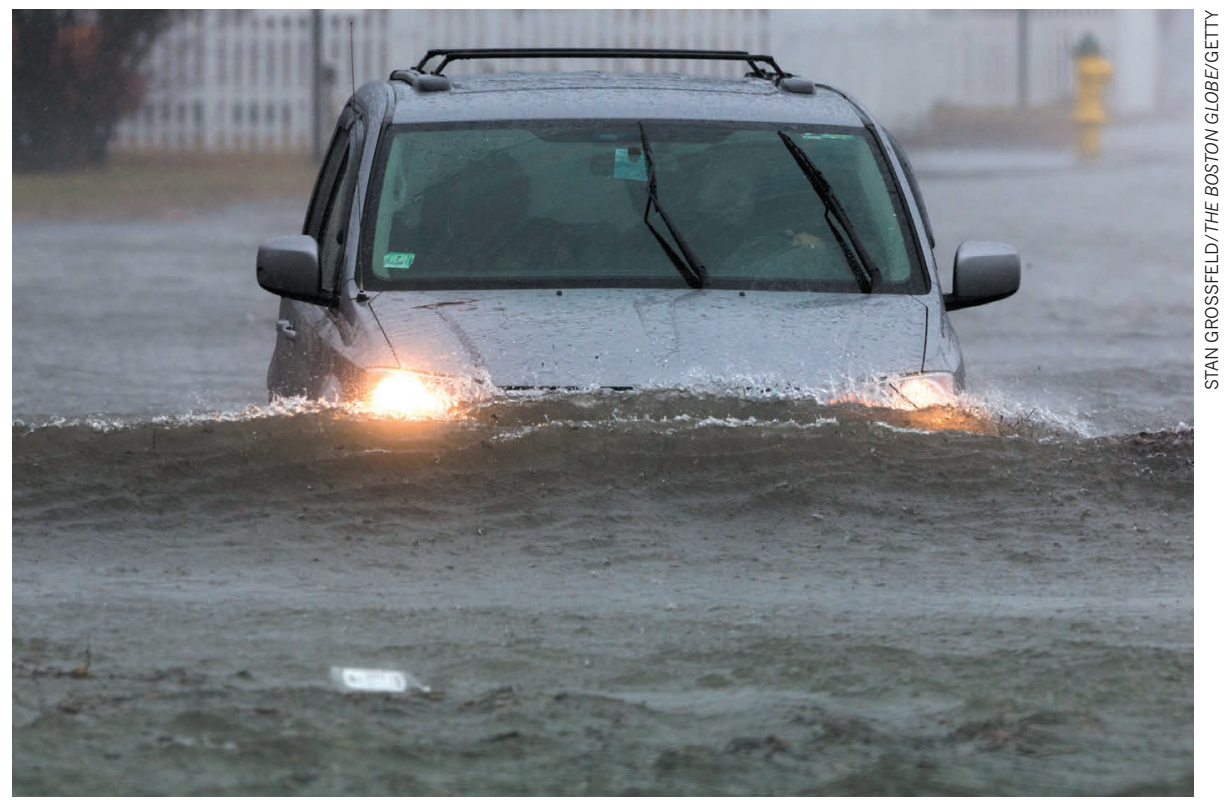

Climate change is likely to exacerbate extreme weather. 
when we tend to vilify and marginalize other voices. We need to have everyone at the table."

When pressed by Republican and Democratic committee members about climate change, Droegemeier offered little, other than saying that bringing the weather and climatemodelling communities together could improve forecasts.

If confirmed, the meteorologist would join an administration that has sought to cut climate-change programmes at the Environmental Protection Agency and roll back federal regulations on greenhouse-gas emissions.

Scientists were largely encouraged when Trump nominated Droegemeier to lead the OSTP, which helps to coordinate science policy and spending between federal agencies. And Neal Lane, a physicist who served as science adviser to former president Bill Clinton, remained optimistic. "No one in Congress is going to say extreme weather events are not important," he said. And linking those episodes with climate science is vital, Lane added. "There's nobody better to do that than Kelvin Droegemeier."

Other questions from lawmakers focused on scientific competition from China and on sexual harassment in research.

"We need to make sure we are the strongest research centre in the world," said Droegemeier. And although welcoming foreign researchers is an important part of science in the United States, he said, it should be done with care.

$\mathrm{He}$ also spoke in favour of a recent National Science Foundation (NSF) policy that requires institutions to report agency-funded researchers who are found to have committed sexual harassment. "We owe all scientists a safe place to work," Droegemeier said. If confirmed to lead the OSTP, he said, he will turn the attention of all agencies under his purview to this issue. He also plans to focus on increasing representation of women and people from under-represented groups in science.
"I think it's a bright day for science," said Lane, who had written to the Senate committee in support of Droegemeier's nomination.

In his opening remarks, Republican Senator James Inhofe of Oklahoma said that Droegemeier has impressive scientific qualifications. The meteorologist was vice-president for research at the University of Oklahoma in Norman from 2009 to 2018 . He stepped down from his position on 20 August, in advance of his confirmation hearing.

Droegemeier also served on the National Science Board, which oversees the NSF, under former presidents Barack Obama and George W. Bush. He is the current secretary of science and technology for Oklahoma.

The Senate committee will vote on 29 August on whether to advance Droegemeier's nomination to the full Senate. If a majority votes for his confirmation, he will be the first non-physicist to take the reins at the OSTP since Congress established the office in 1976 .

\section{India targets fake journals}

\section{The government tells universities to stop promoting predatory publications.}

\section{BY SUBHRA PRIYADARSHINI}

M ost academics regard predatory journals as an irritant - if not a threat - to science. But in India, some universities have recommended the inclusion of such publications in the country's 'white list' of approved journals. Now the government is cracking down on this practice, which scientists say came about as a result of perverse government incentives.

"We will end this menace of predatory journals," Prakash Javadekar, the minister responsible for higher education, told parliament last month. Universities now have until the end of August to revise their recommendations for the journal white list to avoid predatory publications, which actively solicit manuscripts and charge authors hefty fees without providing the services they advertise, such as editing and peer review.

Predatory journals are a problem because research funding is wasted on deceptive publishers that don't deliver what they promised. A major international journalistic investigation, published last month in multiple media outlets, estimated that the number of papers put out by five major predatory publishers has tripled since 2013 - to about 175,000 articles.

Many publishers that host suspected predatory journals are based in India. And multiple studies have found that a high proportion of articles in such journals come

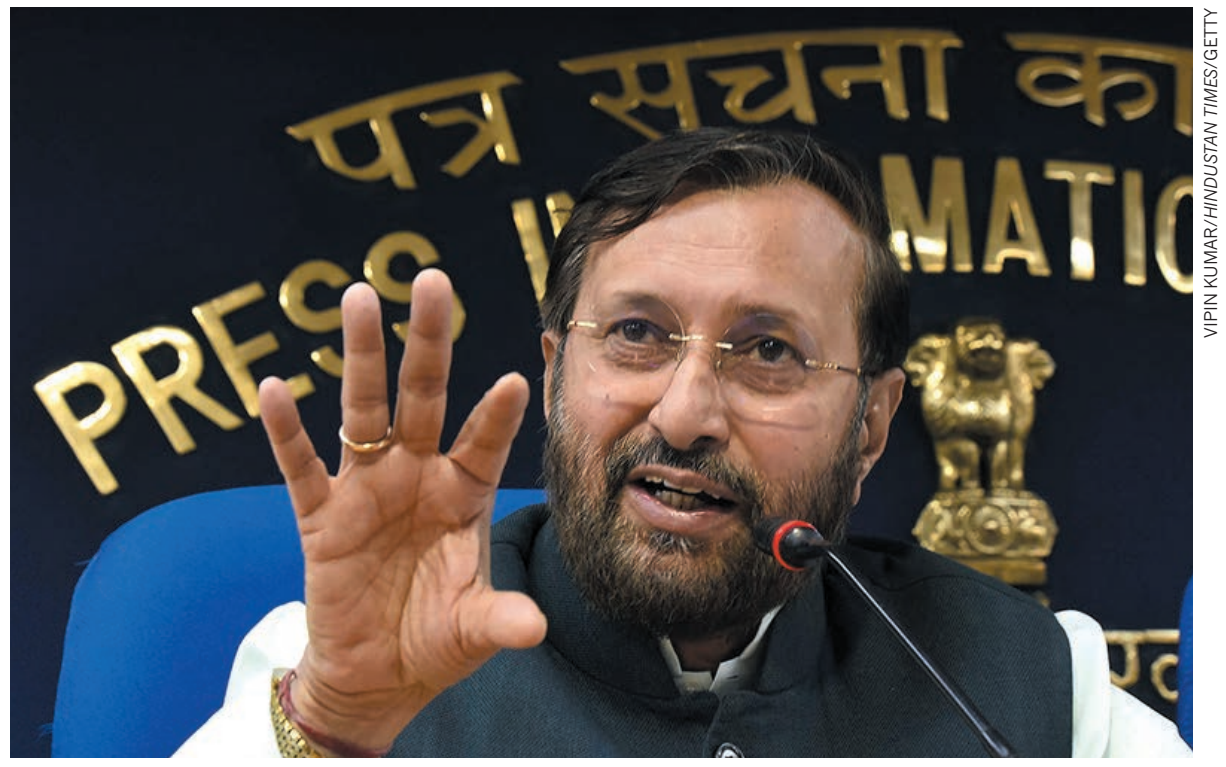

India's universities minister Prakash Javadekar has promised to end the "menace" of predatory journals.

from academics in the country ${ }^{1,2}$.

Many Indian academics blame this situation on the nation's system for assessing academic performance. In 2010, India's higher-education regulatory and funding agency, the University Grants Commission (UGC), introduced a system for evaluating academics called the Academic Performance Indicator, which places considerable weight on the number of research publications. Universities must use the indicator to hire and promote faculty members. But scientists have complained that this encourages academics and universities to focus on the quantity of publications, rather than their quality.

To reduce the practice of publishing in sub-standard journals, the UGC released a white list of approved journals in January 2017. The list contained approximately 32,000 publications indexed on science-citation 